\title{
HUBUNGAN KOMUNIKASI EFEKTIF ORANGTUA TENTANG PENDIDIKAN SEKS DENGAN PERILAKU SEKS BEBAS PADA REMAJA DI SMA KEMALA BHAYANGKARI 1 JAKARTA PADA BULAN JUNI TAHUN 2015
}

\author{
Indah Lailliyah Rahmawati ${ }^{1}$, Diah Ratnawati ${ }^{2}$ \\ S1 Keperawatan Fakultas Ilmu-ilmu Kesehatan \\ Universitas Pembangunan Nasional "Veteran" Jakarta \\ Jln. Limo Raya, Depok \\ Telp : 08877897768/E-mail : Indahlailliyahrahmawati@ymail.com
}

\begin{abstract}
Sexuality cases were complicated problem for adolescent phase was phase when someone faced into several odds and problems both of development and environment that affected to sexuality practice of adolescent. This study was conducted to know relationship of parents " communaction with sexual practive students SMA Kemala Bhayangkari 1". This study was analytic descriptive quantitatif with cross sectional method, sample size were 150 responden. Analysis was by using Chi Square to analyze relantionship between child-parents" Communication with sexual practice that influenced by students SMA Kemala Bhayangkari 1 (old, gender and knowledge) and parent characteristics (family type). The result by using univariane showed that 68 respondents $(45,3 \%)$ had negative sexual practice and 133 responden $(88,7 \%)$ has good communication with their parent. Bivariate analysis showed that there were significant relationship between old $(P=0,000)$ gender $(P=0,017)$ knowledge $(P=0,007)$ and communication with parents $(P=0,001)$ to sexual practice of student. Suggestion present to parents to promote friendly family condition so it shall be able to create open communication about reproductive health and sexuality.
\end{abstract}

Keywords : adolescent, communication parents with adolescent, sexuality knowledge and sexual practice.

\section{PENDAHULUAN}

Perilaku seksual remaja sudah menjamur di belahan dunia, baik di negara maju maupun negara berkembang. Terjadi peningkatan jumlah remaja dalam 20 tahun terakhir ini yang melakukan berhubungan seks pra nikah seperti di Inggris, Amerika serikat, Kanada, dan
Australia. Remaja berhubungan seks pra nikah sebanyak $17 \%$ pada usia sebelum 16 tahun dan ketika usia 19 tahun, tiga perempat remaja satu kali melakukan seks pra nikah. Selain itu, di Negara-negara Asia seperti Thailand, China, dan Rusia sekitar 135 remaja sudah melakukan hubungan seks pra nikah pada umur 15-17 tahun. 
Boyke (2009, hlm.23) menyatakan hasil survei dari 33 Provinsi di Indonesia pada tahun 2008 menunjukkan bahwa $63 \%$ remaja SMA pernah berhubungan seks. Angka ini naik dibandingkan dengan tahun-tahun sebelumnya yaitu penelitian BKKBN tahun 2005-2006 di kota-kota besar seperti di Jakarta (35,9\%), Bekasi (51\%) Medan (52\%), Bandung (47\%), Surabaya (54\%) dan Yogyakarta (37\%) remaja mengaku melakukan hubungan seks sebelum menikah sehingga remaja rentan resiko gangguan kesehatan seperti penyakit HIV/AIDS (Human Immuno Virus/Acquired Immuno Deficiency Syndrome).

Perilaku seks bebas atau premarital intercourse adalah sebagai bentuk perilaku atau aktivitas seksual yang dilakukan tanpa adanya ikatan perkawinan (Amrillah 2006, hlm.45). Perilaku seks bebas adalah hubungan seksual antara dua individu tanpa ikatan perkawinan. Objek seksual dapat berupa orang, baik sejenis maupun lawan jenis, orang dalam khayalan atau diri sendiri (Sarwono 2010, hlm.174). Penyebab perilaku seksual dipengaruhi oleh faktor internal merupakan faktor yang berasal dari dalam individu yang berupa bekerjanya hormon alat reproduksi sehingga menimbulkan dorongan seksual yang menuntut untuk segera tersalurkan, sedangkan faktor eksternal merupakan faktor yang berasal dari luar individu yang menimbulkan dorongan seksual sehingga memunculkan perilaku seksual (Nurhayati 2011, hlm.56).

Keluarga merupakan tempat pertama bagi remaja dalam mendapatkan pendidikan. Adanya komunikasi yang bersifat timbal balik antara orang tua dan anak remajanya, maka segala konflik yang timbul akan mudah diatasi. Sebaliknya, komunikasi yang kaku, dingin, terbatas, menekan penuh otoritas, hanya akan memunculkan berbagai konflik yang berkepanjangan sehingga suasana menjadi tegang, panas, emosional, sehingga dapat menyebabkan hubungan sosial antara satu sama lain menjadi rusak.

Pengetahuan seksualitas yang diberikan dengan tepat oleh orang tua menggunakan komunikasi kepada anak remajanya hanya dapat 
dilakukan bila orang tua dilihat sebagai sahabat remaja. Remaja biasanya telah mempunyai informasi seks sebelum orang tua mulai berbicara mengenai pendidikan seks. Sifat anak dan orang tua bermacammacam, sehingga tidak ada satu cara yang sama yang dapat diterapkan disegala situasi untuk semua remaja disemua lingkungan, namun demikian ada beberapa hal yang perlu diperhatikan oleh orang tua sebelum memberikan pengetahuan tentang pendidikan seks kepada anak remajanya

Studi pendahuluan yang dilakukan oleh peneliti terhadap 10 siswa-siswi SMA Kemala Bhayangkari 1 jurusan IPA dan IPS kelas XI ditemukan 6 remaja mengakui telah melakukan perilaku seksual ringan pranikah seperti (menaksir, pergi, berkencan, menghayal, berpegangan tangan, berciuman ringan (kening, pipi) dan saling memeluk) sedangkan 4 remaja ditemukan telah melakukan perilaku seksual berat pra nikah seperti (berciuman bibir, mulut dan lidah, meraba atau mencium bagian sensitif seperti payudara dan alat kelamin, oral seks, dan berhubungan seks atau senggama).
Berdasarkan uraian diatas, dapat disimpulkan bahwa perhatian terhadap pergaulan remaja dan pola komunikasi orang tua terhadap anak sangat diperlukan dikalangan remaja, terutama pada remaja putri. Oleh karena itu, peneliti sangat tertarik untuk meneliti seberapa besar hubungan komunikasi efektif orang tua tentang pendidikan seks dengan perilaku seks bebas pada remaja di SMA Kemala Bhayangkari 1 pada bulan Juni tahun 2015.

\section{METODE PENELITIAN}

Penelitian ini menggunakan cross sectional dengan deskripsi korelasi digunakan untuk untuk melihat hubungan antara komunikasi efektif orang tua tentang pendidikan seks dengan perilaku seks bebas pada remaja di SMA Kemala Bhayangkari 1 pada bulan Juni tahun 2015. Penelitian dilakukan di SMA Kemala Bhayangkari 1 yang terletak di komplek Polri Ampera. Penelitian ini menggunakan metode non random sampling. Tekhnik yang diambil adalah dengan tehnik total sampling yaitu pengambilan sampel secara keseluruhan dengan jumlah total sampel 150 responden. Variabel 
independent pada penelitian ini adalah hubungan komunikasi orang tua dengan perilaku seks bebas pada remaja untuk variabel independent adalah perilaku seks bebas pada remaja.

\section{HASIL PENELITIAN}

Berikut ini akan dibahas mengenai hasil mulai dari analisis univariat dan bivariat :

\section{a. Analisis Univariat}

Tabel 1. Distribusi Frekuensi

Responden Berdasarkan Usia

\begin{tabular}{|l|c|c|}
\hline \multicolumn{1}{|c|}{ Responden } \\
\hline$<16$ tahun & Frekuensi & $\begin{array}{c}\text { Persen } \\
(\mathbf{\%})\end{array}$ \\
\hline$\geq 16$ tahun & 106 & 29,3 \\
\hline Total & $\mathbf{1 5 0}$ & $\mathbf{1 0 0 , 0}$ \\
\hline
\end{tabular}

Pada tabel 4.1 menunjukkan bahwa dari 150 responden yang diteliti, jumlah responden yang berusia kurang dari 16 tahun sebanyak 44 responden dengan jumlah persentasi sebanyak $(29,3 \%)$ dan jumlah responden yang berusia lebih dari 16 tahun sebanyak 106 responden dengan persentasi sebanyak $(70,7 \%)$. Hasil penelitian ini sesuai dengan penelitian yang dilakukan oleh Ririn (2009), dengan penelitian berjudul "Faktor Yang Mempengaruhi
Perilaku Seks Pranikah Pada Remaja SMA Di Surakarta", dengan hasil persentase terbesar umur responden 17 tahun yaitu sebanyak 73 orang $(64,3 \%)$, sedangkan persentase terkecil adalah umur 15 tahun yaitu sebanyak 13 orang $(11,4 \%)$.

Tabel 2. Distribusi Frekuensi

Responden Berdasarkan Jenis Kelamin

\begin{tabular}{|l|c|c|}
\hline $\begin{array}{c}\text { Jenis } \\
\text { kelamin }\end{array}$ & Frekuensi & $\begin{array}{c}\text { Persen } \\
(\boldsymbol{\%})\end{array}$ \\
\hline Laki-laki & 89 & 59,3 \\
\hline Perempuan & 61 & 40,7 \\
\hline Total & $\mathbf{1 5 0}$ & $\mathbf{1 0 0 , 0}$ \\
\hline
\end{tabular}

Pada tabel 4.2 menunjukkan bahwa dari 150 responden yang diteliti, jumlah responden yang berjenis kelamin laki-laki sebanyak 89 responden dengan jumlah persentasi sebanyak $(59,3 \%)$ dan responden yang berjenis kelamin perempuan sebanyak 61 responden dengan jumlah persentasi sebanyak $(40,7 \%)$. Hasil penelitian ini sesuai dengan hasil penelitian yang dilakukan oleh Fadhila (2010), dengan judul penelitian "Hubungan Antara Pengetahuan Dengan Sikap Seksual Pranikah Remaja" yang menunjukkan remaja laki-laki lebih banyak sebanyak 95 orang $(51,63 \%)$ dan remaja wanita sebanyak 89 orang. 
Tabel 3. Distribusi Frekuensi

Responden Berdasarkan Tipe

Keluarga

\begin{tabular}{|l|l|l|}
\hline Jenis Kelamin & $\begin{array}{c}\text { Frekuens } \\
\mathbf{i}\end{array}$ & $\begin{array}{c}\text { Persen } \\
(\mathbf{\%})\end{array}$ \\
\hline Keluarga inti & 130 & 86,7 \\
\hline $\begin{array}{l}\text { Keluarga } \\
\text { besar }\end{array}$ & 20 & 13,3 \\
\hline Total & $\mathbf{1 5 0}$ & $\mathbf{1 0 0 , 0}$ \\
\hline
\end{tabular}

Pada tabel 3 menunjukkan bahwa dari 150 responden yang diteliti, terdapat 130 responden dengan jumlah persentasi sebanyak $(86,7 \%)$ dengan tipe keluarga inti (nuclear family) dan 20 responden dengan jumlah persentasi sebanyak $(13,3)$ yang memiliki tipe keluarga besar (extended family). Pengkategorian diatas yaitu tipe keluarga inti dan keluarga besar dilihat dari latar tempat tinggal remaja.

Tabel 4. Distribusi Frekuensi Responden Berdasarkan Pengetahuan

\begin{tabular}{|l|c|c|}
\hline Pengetahuan & Frekuensi & $\begin{array}{c}\text { Persen } \\
(\boldsymbol{\%})\end{array}$ \\
\hline Rendah & 85 & 56,7 \\
\hline Tinggi & 65 & 43,3 \\
\hline Total & $\mathbf{1 5 0}$ & $\mathbf{1 0 0 , 0}$ \\
\hline
\end{tabular}

Pada tabel 4 menunjukkan bahwa dari 150 responden yang diteliti, terdapat 85 responden dengan jumlah persentasi sebanyak $(56,7 \%)$ yang pengetahuan seksualitasnya rendah dan 65 responden dengan jumlah persentasi sebanyak $(43,3 \%)$ yang pengetahuannya tinggi. Hasil penelitian ini sesuai dengan penelitian yang dilakukan oleh Maryatun (2012), dengan judul hubungan "Pengetahuan Dan Peran Keluarga Dengan Perilaku Seksual Pranikah Pada Remaja Anak Jalanan Di Kota Surakarta", dengan hasil tabel frekuensi sebanyak 43 responden $(82,7 \%)$ yang pengetahuannya rendah dan sebanyak 27 responden $(51,9)$ yang pengetahuannya tinggi.

Tabel 5. Distribusi Frekuensi Responden Berdasarkan Komunikasi Dengan Orang Tua

\begin{tabular}{|l|l|l|}
\hline Komunikasi & Frekuensi & $\begin{array}{c}\text { Persen } \\
(\boldsymbol{\%})\end{array}$ \\
\hline Tidak Efektif & 40 & 26,7 \\
\hline Efektif & 110 & 73,3 \\
\hline Total & $\mathbf{1 5 0}$ & $\mathbf{1 0 0 , 0}$ \\
\hline
\end{tabular}

Pada tabel 5 menunjukkan bahwa dari 150 responden yang diteliti, terdapat 40 responden dengan jumlah persentasi sebanyak $(26,7 \%)$ yang memiliki komunikasi tidak efektif atau tidak baik dengan orang tuanya dan 110 responden dengan jumlah persentasi sebanyak $(73,3 \%)$ yang memiliki komunikasi efektif atau baik dengan orang tuanya. 
Tabel 6. Distribusi Frekuensi Responden Berdasarkan Perilaku Seksual

\begin{tabular}{|l|l|l|}
\hline $\begin{array}{l}\text { Perilaku } \\
\text { seksual }\end{array}$ & Frekuensi & $\begin{array}{l}\text { Persen } \\
(\boldsymbol{\%})\end{array}$ \\
\hline Negatif & 68 & 45,3 \\
\hline Positif & 82 & 54,7 \\
\hline Total & $\mathbf{1 5 0}$ & $\mathbf{1 0 0 , 0}$ \\
\hline
\end{tabular}

Pada tabel 6 menunjukkan bahwa dari 150 responden yang diteliti, terdapat 68 responden dengan jumlah persentasi sebanyak $(45,3 \%)$ yang memiliki perilaku seksual negatif dan 82 responden dengan jumlah persentasi sebanyak $(54,7 \%)$ yang memiliki perilaku seksual positif

\section{b. Analisa Bivariat}

1. Hubungan Usia Dengan Perilaku Seksual

Tabel 7. Hubungan Antara Usia Dengan Perilaku Seksual Pada SiswaSiswi Kelas XI IPA Dan IPS SMA Kemala Bhayangkari 1 Pada Bulan Juni Tahun 2015.

\begin{tabular}{|c|c|c|c|c|c|c|c|c|}
\hline \multirow[t]{3}{*}{ Usia } & \multicolumn{4}{|c|}{ Perilaku seksual } & \multirow{2}{*}{\multicolumn{2}{|c|}{ Total }} & \multirow{3}{*}{$\begin{array}{l}\text { OR } \\
95 \% \mathrm{CI}\end{array}$} & \multirow{3}{*}{$\begin{array}{l}\text { P } \\
\text { Value }\end{array}$} \\
\hline & \multicolumn{2}{|c|}{ Negatif } & \multicolumn{2}{|c|}{ Positif } & & & & \\
\hline & $\mathrm{N}$ & $\%$ & $\mathrm{~N}$ & $\%$ & $\mathrm{~N}$ & $\%$ & & \\
\hline $\begin{array}{l}<16 \\
\text { tahun }\end{array}$ & 4 & 91 & 40 & 90,9 & 44 & 100,0 & 0,066 & \\
\hline $\begin{array}{l}\geq 16 \\
\text { tahun }\end{array}$ & 64 & 60,4 & 42 & 39,6 & 106 & 100,0 & $\begin{array}{l}(0,022- \\
0,197)\end{array}$ & 0,000 \\
\hline Total & 68 & 45,3 & 82 & 54,7 & 150 & 100,0 & & \\
\hline
\end{tabular}

Pada tabel 7 menunjukkan bahwa dari 150 responden yang diteliti, terdapat 44 responden yang berusia kurang dari 16 tahun , sebanyak 4 responden $(91,9 \%)$ yang memiliki perilaku seksual negatif dan sebanyak 40 responden $(90,9 \%)$ yang memiliki perilaku seksual positif. Hasil penelitian juga terdapat 106 responden yang berusia lebih dari 16 tahun sebanyak 64 responden $(60,4 \%)$ yang berperilaku seksual negatif dan 42 responden $(39,6 \%)$ yang berperilaku seksual positif.

Hasil uji statistik terlihat bahwa $\mathrm{P}$ Value 0,000 lebih kecil dari nilai alpha 0,05 , sehingga dapat disimpulkan bahwa ada hubungan yang bermakna antara usia responden dengan perilaku seksual siswa-siswi SMA Kemala Bhayangkari 1 pada bulan Juni tahun 2015. Interpretasi dari nilai uji odd ratio menunjukkan bahwa responden yang usianya lebih dari 16 tahun berpeluang 0,066 kali berperilaku seksual negatif dibandingkan dengan responden yang usianya kurang dari 16 tahun, akan tetapi hal ini tidak terbukti secara statistik (nilai $\mathrm{P}>0,05$ ). 
Usia mulai pacaran sebelum usia 15 tahun pada wanita $24 \%$ dan pria 19\%. Hasil Riset Kesehatan Dasar (RISKESDAS) tahun 2010 yang menyatakan bahwa dari 63.048 remaja usia 10-24 tahun yang belum menikah adalah $86,7 \%$. Remaja yang melakukan hubungan seksual pertama kali pada usia lebih dari 17 tahun adalah 76,4\%, sedangkan remaja yang melakukan hubungan seksual pertama kali pada usia dibawah 17 tahun adalah 10,3\%. Pada usia 15 tahun mereka biasanya hanya melakukan pegangan tangan, cium bibir dan meraba atau merangsang, sedangkan pada remaja yang sudah berusia diatas 16 tahun biasanya sudah mulai berani melakukan hubungan seksual tanpa memikirkan akibatnya.

Hasil RISKESDAS tersebut juga mengidentifikasi bahwa umur pertama kali melakukan hubungan seksual sudah terjadi pada usia muda, yaitu 8 tahun, dengan data $0,5 \%$ perempuan telah melakukan hubungan seksual pertama kali pada usia 8 tahun dan 0,1 pada laki-laki. Kelompok remaja awal mengalami perkembangan seks primer yang memerlukan adaptasi remaja secara fisik, psikologis, dan sosial.

Hasil penelitian ini tidak sejalan dengan penelitian yang dilakukan oleh Harnomsari (2011), dengan judul "Hubungan Kelompok Teman Sebaya Dengan Perilaku Berpacaran Pada Remaja Usia 1417 Di SMK SANDIKTA BEKASI", yang menunjukkan bahwa hasil uji statistik didapatkan nilai $\mathrm{P}$ value $=0,784$, berarti $\mathrm{P}$ value > 0,05 dapat disimpulkan tidak terdapat hubungan antara usia dengan perilaku berpacaran pada remaja di SMK SANDIKTA

\section{BEKASI.}

Hasil penelitian ini sesuai dengan penelitian yang dilakukan untuk mengidentifikasi perilaku seksual pada remaja di USA tahun 2006 yang menunjukkan hasil bahwa 358 gadis remaja usia 14-17 tahun telah melakukan salah satu dari delapan perilaku seksual yaitu ciuman, menyentuh payudara, menyentuh alat kelamin, menyentuh sekitar genital, melakukan oral seks, anal seks atau vaginal seks (Fortenberry, et al, 2011). 
Survai Kesehatan Republik Remaja Indonesia (SKRRI) pada tahun 2007 menunjukkan hasil bahwa usia pertama kali pacaran adalah 15-17 tahun, proporsi wanita $43 \%$ dan pria $40 \%$. Usia mulai pacaran sebelum usia 15 tahun pada wanita $24 \%$ dan pria 19\%. Thera (2005) menyatakan bahwa remaja adalah masa peralihan dari kanak-kanak ke dewasa. Selama masa peralihan tersebut, remaja akan mencoba dan beradaptasi dengan gaya hidup perilaku seksual dengan bertambahnya usia remaja. Hal tersebut akan mendorong gaya hidup dan perilaku remaja yang tidak sehat. Gaya hidup ataupun perilaku maladaptif remaja sejalan dengan bertambahnya usia remaja maka secara kumulatif akan mengakibatkan perilaku seksual remaja yang dimulai saat usia awal remaja selama masa transisi pubertas remaja.

Kesimpulan dalam penelitian ini adalah remaja yang usianya lebih dari 16 tahun lebih beresiko melakukan hubungan seksual, dilihat dari penelitian yang sudah dilakukan bahwa sebanyak 106 responden yang berusia lebih dari 16 tahun sebanyak 64 responden $(60,4 \%)$ yang berperilaku seksual negatif dan 42 responden $(39,6 \%)$ yang berperilaku seksual positif.

2. Hubungan Jenis Kelamin Dengan Perilaku Seksual

Tabel 8. Hubungan Antara Jenis Kelamin Dengan Perilaku Seksual Pada Siswa-Siswi Kelas XI IPA Dan IPS SMA Kemala Bhayangkari 1 Pada Bulan Juni Tahun 2015.

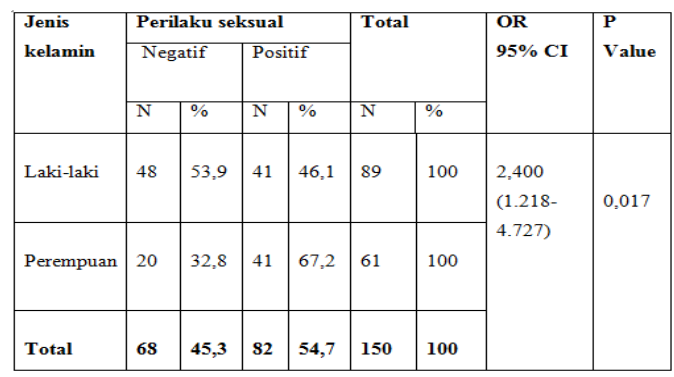

Pada tabel 4.8 menunjukkan bahwa dari 150 responden yang diteliti, terdapat 89 responden yang berjenis kelamin laki-laki, ternyata sebagian besar memiliki perilaku seksual negatif sebanyak 48 responden $(53,9 \%)$ sedangkan 41 responden $(46,1 \%)$ yang berperilaku seksual positif. Hasil penelitian ini juga menunjukkan bahwa sebanyak 61 responden yang berjenis kelamin perempuan terdapat 20 responden $(32,8 \%)$ yang berperilaku negatif dan 41 responden $(67,2 \%)$ yang berperilaku seksual positif. Hasil uji statistik terlihat bahwa nilai $\mathrm{P}$ Value 0,017 lebih kecil dari nilai alpha 0,05, sehingga dapat disimpulkan bahwa 
ada hubungan yang bermakna antara jenis kelamin dengan perilaku seksual siswa-siswi SMA Kemala Bhayangkari 1 pada bulan Juni tahun 2015. Interpretasi dari nilai uji odd ratio menunjukkan bahwa responden yang berjenis kelamin laki-laki berpeluang 2,400 kali berperilaku seksual negatif dari pada responden perempuan, akan tetapi hal ini tidak terbukti secara statistic (nilai $\mathrm{P}>0,05$ ). Sesuai teori yang dinyatakan bahwa bagi laki-laki ketertarikannya pada lawan jenis lebih pada pemenuhan kebutuhan seksual (sexual interest), karena bagi remaja laki-laki cinta adalah seks (Depkes,2005). Berbeda dengan remaja perempuan yang ketertarikannya pada lawan jenis lebih pada kebutuhan untuk harga diri, kasih sayang, dan cinta.

Hasil penelitian ini sesuai dengan penelitian yang dilakukan Sanjaya (2008) dengan judul "Hubungan Komunikasi Orang Tua Dengan Perilaku Seksual Mahasiswa S1 Tehnik Informatika Angkatan 2007/2008 Di Universitas Pembangunan Nasional "UPN" Veteran", yang menunjukkan sebanyak 51 responden yang berjenis laki-laki sedangkan sebanyak 49 responden yang berjenis kelamin wanita dengan hasil $\mathrm{P}$ value 0,017 lebih kecil dari nilai alpha 0,05, sehingga dapat disimpulkan ada hubungan bermakna antara jenis kelamin dengan perilaku seksual mahasiswa S1 program studi ilmu keperawatan dan S1 tehnik informatika angkatan 2007/2008 di UPN “Veteran”. (2003).

Hasil penelitian ini tidak sesuai dengan penelitian yang dilakukan oleh Nurfitria (2012), dengan judul "Gambaran Perilaku Seksual remaja Di Sekolah Menengah kejuruan(SMK) Swastta X2 Di Kota Depok Tahun 2012", bahwa sebagian besar jenis kelamin dalam penelitian ini adalah perempuan, dimana perilaku seksual siswa-siswi perempuan tidak berlebihan dibandingkan dengan laki-laki.

Kesimpulan dari penelitian ini adalah lebih banyak responden yang berjenis kelamin laki-laki yang beresiko melakukan perilaku seksual, hasil ini sesuai dengan hasil penelitian yang sudah dilakukan yang menunjukkan bahwa sebanyak 89 responden yang berjenis kelamin laki-laki, ternyata sebagian besar memiliki perilaku 
seksual negatif sebanyak 48 responden $(53,9 \%)$ sedangkan sebanyak 61 responden yang berjenis kelamin perempuan terdapat 20 responden $(32,8 \%)$ yang berperilaku negatif.

3. Hubungan Tipe Keluarga Dengan Perilaku Seksual

Tabel 9. Hubungan Antara Tipe Keluarga Dengan Perilaku Seksual Pada Siswa-Siswi Kelas XI IPA Dan IPS SMA Kemala Bhayangkari 1 Pada Bulan Juni Tahun 2015.

\begin{tabular}{|c|c|c|c|c|c|c|c|c|}
\hline \multirow{3}{*}{\begin{tabular}{|l|} 
Tipe \\
Keluarga
\end{tabular}} & \multicolumn{4}{|c|}{ Perilaku seksual } & \multirow{2}{*}{\multicolumn{2}{|c|}{ Total }} & \multirow{3}{*}{$\begin{array}{l}\text { OR } \\
95 \% \mathrm{CI}\end{array}$} & \multirow{3}{*}{$\begin{array}{l}\text { P } \\
\text { Value }\end{array}$} \\
\hline & \multicolumn{2}{|c|}{ Negatif } & \multicolumn{2}{|c|}{ Positif } & & & & \\
\hline & $\mathrm{N}$ & $\%$ & $\mathrm{~N}$ & $\%$ & $\mathrm{~N}$ & $\%$ & & \\
\hline $\begin{array}{l}\text { Keluarga } \\
\text { Inti }\end{array}$ & 58 & 44,6 & 72 & 55,4 & 130 & 100,0 & 0,806 & \\
\hline $\begin{array}{l}\text { Keluarga } \\
\text { Besar }\end{array}$ & 10 & 50,0 & 10 & 50,0 & 20 & 100,0 & $\begin{array}{l}(0,314- \\
2,067)\end{array}$ & 0,834 \\
\hline Total & 68 & 45,3 & 82 & 54,7 & 150 & 100,0 & & \\
\hline
\end{tabular}

Pada tabel 4.9 menunjukkan bahwa dari 150 responden yang diteliti, terdapat 130 responden yang berasal dari keluarga inti, sebanyak 58 responden $(44,6 \%)$ yang berperilaku seksual negatif dan 72 responden $(55,4 \%)$ yang berperilaku seksual positif.

Hasil penelitian ini juga menunjukkan bahwa sebanyak 20 responden yang berasal dari keluarga besar, sebanyak 10 responden $\quad(50,0 \%) \quad$ yang berperilaku seksual negatif dan 10 responden $\quad(50,0 \%) \quad$ yang berperilaku seksual positif.

Hasil Uji statistik menunjukkan bahwa nilai $\mathrm{P}$ Value 0,834 lebih besar dari nilai alpha 0,05, sehingga dapat disimpulkan bahwa tidak ada hubungan yang bermakna antara tipe keluarga dengan perilaku seksual siswasiswi SMA Kemala Bhayangkari 1 tahun 2015. Interpretasi dari nilai uji odd ratio menunjukkan bahwa responden yang berasal dari keluarga dengan tipe keluarga inti (nuclear family) berpeluang 0, 806 kali berperilaku seksual positif dibandingkan dengan responden dengan tipe keluarga besar (extended family), akan tetapi hal ini tidak terbukti secara statistic (nilai $\mathrm{P}>0,05$ ).

Hasil penelitian ini tidak sesuai dengan hasil penelitian yang dilakukan oleh Sanjaya (2008) yang berjudul "Hubungan Komunikasi Orang Tua Dengan Perilaku Seksual Mahasiswa S1 Tehnik Informatika Angkatan 2007/2008 Di Universitas Pembangunan Nasional "Veteran" 
Jakarta, yang menunjukkan sebanyak 90 responden $(90,0 \%)$ yang berasal dari keluarga inti dan sebanyak 10 responden $(10,0 \%)$ responden yang berasal dari keluarga besar. Hasil uji statustik menunjukkan bahwa nilai $\mathrm{P}$ value 0,041 lebih kecil dari nilai alpha 0,05 , sehingga dapat disimpulkan bahwa ada hubungan yang bermakna antara tipe keluarga dengan perilaku seksual mahasiswa S1 program Studi Ilmu Keperawatan dan S1 Tehnik Informatika Angkatan 2007/2008 di UPN "Veteran".

Kesimpulan dari penelitian ini adalah anak remaja yang tinggal bersama orang tua tidak ada hubungannya dengan perilaku seksual remaja karena remaja kurang mendapatkan pengawasan jika hanya dari orang tuanya saja. Hasil penelitian yang menunjukkan bahwa sebanyak 130 responden yang berasal dari keluarga inti, sebanyak 58 responden $\quad(44,6 \%) \quad$ yang berperilaku seksual negatif dan 72 responden $\quad(55,4 \%) \quad$ yang berperilaku seksual positif, hasil uji statistik menunjukkan bahwa nilai $\mathrm{P}$ Value 0,834 lebih besar dari nilai alpha 0,05 , sehingga dapat disimpulkan bahwa tidak ada hubungan yang bermakna antara tipe keluarga dengan perilaku seksual.

3. Hubungan

Pengetahuan Responden Dengan Perilaku Seksual

Tabel 9. Hubungan Antara Pengetahuan Responden Dengan Perilaku Seksual Pada Siswa-Siswi Kelas XI IPA Dan IPS SMA Kemala Bhayangkari 1 Pada Bulan Juni Tahun 2015.

\begin{tabular}{|c|c|c|c|c|c|c|c|c|}
\hline \multirow{3}{*}{ Pengetahuan } & \multicolumn{4}{|c|}{ Perilaku seksual } & \multirow{2}{*}{\multicolumn{2}{|c|}{ Total }} & \multirow{3}{*}{$\begin{array}{l}\text { OR } \\
95 \% \mathrm{CI}\end{array}$} & \multirow{3}{*}{$\begin{array}{l}\text { P } \\
\text { Value }\end{array}$} \\
\hline & \multicolumn{2}{|c|}{ Negatif } & \multicolumn{2}{|c|}{ Positif } & & & & \\
\hline & $\mathrm{N}$ & $\%$ & $\mathrm{~N}$ & $\%$ & $\mathrm{~N}$ & $\%$ & & \\
\hline Rendah & 45 & 52,9 & 40 & 47,1 & 85 & 100,0 & & \\
\hline Tinggi & 23 & 35,4 & 42 & 64,6 & 65 & 100,0 & $\begin{array}{l}(1.058- \\
3.988)\end{array}$ & \\
\hline Total & 68 & 45,3 & 82 & 54,7 & 150 & 100,0 & & \\
\hline
\end{tabular}

Pada tabel 4.10 menunjukkan dari 150 responden yang diteliti, terdapat 85 responden yang memiliki pengetahuan yang rendah tentang seksualitas, sebanyak 45 responden (52,9\%) yang berperilaku seksual negatif dan ada 40 responden $(47,1 \%)$ yang berperilaku seksual positif. Hasil penelitian ini juga menunjukkan bahwa sebanyak 65 responden yang memiliki 
pengetahuan tinggi sebanyak 23 responden $(35,4 \%)$ yang berperilaku seksual negatif dan ada 42 responden $(64,6 \%)$ yang berperilaku seksual positif.

Hasil Uji statistik menunjukkan nilai P Value 0,048 lebih kecil dari nilai alpha $\quad 0,05$ sehingga dapat disimpulkan bahwa ada hubungan yang bermakna antara pengetahuan tentang pendidikan seksualitas dengan perilaku seksual siswa-siswi SMA kemala Bhayangkari 1 tahun 2015. Interpretasi dari nilai uji odd ratio menunjukkan bahwa responden yang memiliki pengetahuan rendah berpeluang 2,646 berperilaku seksual negatif dibandingkan dengan responden yang memiliki pengetahuan yang rendah terhadap seksualitas, akan tetapi hal ini tidak terbukti secara statistik (nilai $\mathrm{P}>0.05$ ).

Menurut Syarifrudin (2008), pengetahuan yang setengah-setengah justru lebih berbahaya dari pada tidak tahu sama sekali. Pembentukan pengetahuan sendiri dipengaruhi oleh faktor internal yaitu cara individu dalam menanggapi pengetahuan tersebut dan ekstrenal yang merupakan stimulus untuk mengubah pengetahuan tersebut menjadi lebih baik lagi. Penelitian ini didukung teori yang menyebutkan bahwa remaja tidak tahu bagaimana cara mencari informasi yang benar tentang kesehatan reproduksi, baik di sekolah maupun dirumah. Peluang diskusi mengenai kesehatan reproduksi sangat terbatas, bahkan banyak orang tua dan guru menganggap bicara mengenai seks itu tabu (Aras, 2007).

Penelitian ini sesuai dengan penelitian yang dilakukan oleh Maryatun (2012), dengan judul "Hubungan Pengetahuan Dan Peran Keluarga Dengan Perilaku Seksual Pra Nikah Pada Remaja Anak Jalanan Di Kota Surakarta", pengetahuan responden dalam penelitian ini dibedakan menjadi dua yaitu pengetahuan kurang dan pengetahuan baik.

Penelitian tersebut juga terdapat analisis tabel yang memperoleh hasil terdapat hubungan yang signifikan antara pengetahuan dan perilaku seksual pra nikah pada anak jalanan di Kota Surakarta.

Penelitian ini tidak sesuai dengan penelitian yang dilakukan oleh 
Sanjaya (2008) dengan "Hubungan Komunikasi Orang Tua Dengan Perilaku Seksual Mahasiswa S1 Teknik Informatika Angkatan 2007/2008 di Universitas Pembangunan Nasional "Veteran Jakarta, yang menunjukkan nilai $\mathrm{P}$ value 1,000 lebih besar dari nilai alpha $0,05, \quad$ sehingga dapat disimpulkan bahwa tidak ada hubungan yang bermakna antara pengetahuan tentang seksualitas dengan perilaku seksual mahasiswa S1 Program Studi Ilmu keperawatan dan S1 Teknik Informatika angkatan 2007/2008 di UPN "Veteran".

Kesimpulan dari penelitian ini adalah tingkat pengetahuan remaja rendah yang disebabkan karena remaja kurang mendapatkan informasiinformasi tentang kesehatan reproduksi. Remaja mendapatkan sumber-sumber informasi dari sumber yang tidak bisa dipercaya atau dipertanggung jawabkan yang membuat remaja bersikap tidak sewajarnya. Hasil penelitian menunjukkan sebanyak 85 responden yang memiliki pengetahuan yang rendah tentang seksualitas, sebanyak 45 responden $(52,9 \%)$ yang berperilaku seksual negatif dan ada 40 responden $(47,1 \%)$ yang berperilaku seksual positif.

5. Hubungan Komunikasi Dengan Orang Tua Terhadap Perilaku Seksual

Tabel 11. Hubungan Antara Komunikasi Dengan Orang Tua Terhadap Perilaku Seksual Pada Siswa-Siswi Kelas XI IPA Dan IPS SMA Kemala Bhayangkari 1 Pada Bulan Juni Tahun 2015.

\begin{tabular}{|c|c|c|c|c|c|c|c|c|}
\hline \multirow[t]{3}{*}{ Komunikasi } & \multicolumn{4}{|c|}{ Perilaku seksual } & \multirow{2}{*}{\multicolumn{2}{|c|}{ Total }} & \multirow{3}{*}{$\begin{array}{l}\text { OR } \\
95 \% \text { CI }\end{array}$} & \multirow{3}{*}{$\begin{array}{l}\mathrm{P} \\
\text { Value }\end{array}$} \\
\hline & \multicolumn{2}{|c|}{ Negatif } & \multicolumn{2}{|c|}{ Positif } & & & & \\
\hline & $\mathrm{N}$ & $\%$ & $\mathrm{~N}$ & $\%$ & $\mathrm{~N}$ & $\%$ & & \\
\hline Tidak Efektif & 25 & 62,5 & 15 & 37,5 & 40 & 100,0 & 2.597 & \\
\hline Efektif & 43 & 39,1 & 67 & 60,9 & 110 & 100,0 & $5.475)$ & 0,018 \\
\hline Total & 68 & 45,3 & 82 & 54,7 & 150 & 100,0 & & \\
\hline
\end{tabular}

Pada tabel 4.11 menunjukkan dari 150 responden yang diteliti, terdapat 40 responden yang memiliki komunikasi tidak efektif atau yang tidak baik dengan orang tuanya, sebanyak 25 responden $(62,5 \%)$ yang berperilaku seksual negatif dan ada 15 responden $(37,5 \%)$ yang berperilaku seksual positif. Hasil penelitian ini juga menunjukkan bahwa sebanyak 110 responden yang memiliki komunikasi efektif atau yang baik dengan orang tuanya, sebanyak 43 responden $(39,1 \%)$ yang berperilaku seksual negatif dan ada 
67 responden $(60,9 \%)$ yang berperilaku seksual positif.

Hasil Uji statistik menunjukkan bahwa nilai P Value 0,018 lebih kecil dari nilai alpha 0,05 , sehingga dapat disimpulkan ada hubungan yang bermakna antara komunikasi orang tua dengan perilaku seksual siswasiswi SMA Kemala Bhayangkari 1 tahun 2015.

Intreprestasi dari nilai uji odd ratio menunjukkan bahwa responden yang memiliki komunikasi efektif dengan orang tua berpeluang 6.827 kali berperilaku seksual positif dibandingkan dengan responden yang memiliki komunikasi tidak efektif dengan orang tuanya, akan tetapi hal ini tidak terbukti secara statistik (nilai $\mathrm{P}>0,05)$. Komunikasi yang terjalin diantara orang tua dengan anak saling terbuka, adanya perhatian dan saling pengertian. Hal ini dikarenakan komunikasi antara orang tua dan anak remaja dapat mengindarkan remaja dari perilaku seksual pranikah. Komunikasi orang tua dengan anak remaja tentang kesehatan reproduksi yang efektif adalah proses penyampaian informasi yang dilandasi adanya kepercayaan, keterbukaan dan dukungan yang positif pada anak agar anak dapat menerima dengan baik apa yang disampaikan oleh orang tua (Rahmat, 2000). secara bersama (Laily dan Matulessy, 2004).

Hasil penelitian ini sesuai dengan penelitian yang dilakukan oleh Rizka (2009), dengan judul "Hubungan Antara Komunikasi Orang Tua -Anak Remaja Tentang Kesehatan Reproduksi Dengan Perilaku Seks Pra nikah Di SMA Negeri 1 Salaman Kabupaten Magelang”, dengan jumlah responden 182 responden yang menunjukkan nilai $\mathrm{P}$ Value $\mathrm{P}=0,011(\mathrm{P}<0,05)$.

Hasil penelitian yang tidak sesuai dengan penelitian yang dilakukan oleh oleh Sanjaya (2008) dengan "Hubungan Komunikasi Orang Tua Dengan Perilaku Seksual Mahasiswa S1 Teknik Informatika Angkatan 2007/2008 Di Universitas Pembangunan Nasional "Veteran" Jakarta, yang menunjukkan nilai $\mathrm{P}$ value 0,287 lebih besar dari nilai alpha $0,05, \quad$ sehingga dapat disimpulkan bahwa tidak ada 
hubungan yang bermakna antara komunikasi orang tua dengan perilaku seksual mahasiswa S1 Program Studi Ilmu Keperawatan dan S1 Teknik Informatika angkatan 2007/2008 di UPN "Veteran" Jakarta.

Kesimpulan dari penelitian ini adalah remaja sudah menunjukkan komunikasi yang baik antara anak dengan orang tua. Hasil penelitian menujukkan bahwa sebanyak 110 responden yang memiliki komunikasi efektif atau yang baik dengan orang tuanya, sebanyak 43 responden $(39,1 \%)$ yang berperilaku seksual negatif dan ada 67 responden $(60,9 \%)$ yang berperilaku seksual positif. Hal ini menunjukkan bahwa keefektifan komunikasi orang tua dan anak sangat berpengaruh terhadap perilaku remaja, dimana komunikasi yang efektif akan memperkecil terjadinya perilaku seks pra nikah pada remaja.

\section{KESIMPULAN}

Sesuai dengan pembahasan hasil penelitian yang dilakukan kepada 150 responden di SMA Kemala Bhayangkari 1 yang masuk dalam kriteria inklusi responden maka dapat disimpulkan sebagai berikut:
1. Hasil dari uji univariat menunjukkan gambaran karakteristik remaja (usia, jenis kelamin, pengetahuan dan perilaku seks). Gambaran pada usia remaja menunjukkan bahwa dari 150 responden yang diteliti, mayoritas jumlah responden yang paling banyak adalah yang berusia lebih dari 16 tahun sebanyak 106 responden $(70,7 \%)$. Pada jenis kelamin mayoritas yang paling banyak adalah yang berjenis kelamin laki-laki sebanyak 89 responden $(59,3 \%)$. Pada tingkat pengetahuan yang paling banyak adalah tingkat pengetahuan rendah sebanyak terdapat 87 responden $(58,0 \%)$ dan pada persentase perilaku seks remaja menunjukkan yang paling tertinggi adalah perilaku seksual positif dengan jumlah 68 responden $(45,3 \%)$.

2. Hasil gambaran dari komunikasi orang tua dengan remaja menunjukkan bahwa dari 150 responden yang diteliti, terdapat 70 responden dengan jumlah persentasi sebanyak $(46,7 \%)$ yang memiliki komunikasi tidak efektif atau tidak baik dengan orang tuanya dan 85 responden dengan 
jumlah persentasi sebanyak $(53,3 \%)$ yang memiliki komunikasi efektif atau baik dengan orang tuanya.

3. Hasil gambaran dari perilaku seks remaja menunjukkan bahwa dari 150 responden yang diteliti, terdapat 68 responden dengan jumlah persentasi sebanyak $(45,3 \%)$ yang memiliki perilaku seksual negatif dan 82 responden dengan jumlah persentasi sebanyak $(54,7 \%)$ yang memiliki perilaku seksual positif.

4. Hasil uji bivariat dari usia dengan perilaku seks remaja menunjukkan bahwa $\mathrm{P}$ Value 0,000 lebih kecil dari nilai alpha 0,05 , sehingga dapat disimpulkan bahwa ada hubungan yang bermakna antara usia responden dengan perilaku seksual siswa-siswi SMA Kemala Bhayangkari 1 pada bulan Juni tahun 2015. Interpretasi dari nilai uji odd ratio menunjukkan bahwa responden yang usianya lebih dari 16 tahun berpeluang 0,066 kali berperilaku seksual negatif dibandingkan dengan responden yang usianya kurang dari 16 tahun, akan tetapi hal ini tidak terbukti secara statistic (nilai $\mathrm{P}>0,05$ ).
5. Hasil uji bivariat dari jenis kelamin dengan perilaku seks remaja menunjukkan bahwa nilai $\mathrm{P}$ Value 0,017 lebih kecil dari nilai alpha 0,05 , sehingga dapat disimpulkan bahwa ada hubungan yang bermakna antara jenis kelamin dengan perilaku seksual siswasiswi SMA Kemala Bhayangkari 1 pada bulan Juni tahun 2015. Interpretasi dari nilai uji odd ratio menunjukkan bahwa responden yang berjenis kelamin laki-laki berpeluang 2,400 kali berperilaku seksual negatif dari pada responden perempuan, akan tetapi hal ini tidak terbukti secara statistic (nilai $\mathrm{P}>0,05$ ).

6. Hasil uji bivariat dari tipe keluarga dengan perilaku seks remaja menunjukkan bahwa nilai $\mathrm{P}$ Value 0,834 lebih besar dari nilai alpha 0,05, sehingga dapat disimpulkan bahwa tidak ada hubungan yang bermakna antara tipe keluarga dengan perilaku seksual siswasiswi SMA Kemala Bhayangkari 1 tahun 2015. Interpretasi dari nilai uji odd ratio menunjukkan bahwa responden yang berasal dari keluarga dengan tipe keluarga inti (nuclear family) berpeluang 0, 806 
kali berperilaku seksual positif dibandingkan dengan responden dengan tipe keluarga besar (extended family), akan tetapi hal ini tidak terbukti secara statistic (nilai $\mathrm{P}>0,05$ ).

7. Hasil uji bivariat dari komunikasi efektif orang tua dengan perilaku seks remaja menunjukkan bahwa nilai P Value 0,018 lebih kecil dari nilai alpha 0,05 , sehingga dapat disimpulkan ada hubungan yang bermakna antara komunikasi orang tua dengan perilaku seksual siswasiswi SMA Kemala Bhayangkari 1 tahun 2015. Intreprestasi dari nilai uji odd ratio menunjukkan bahwa responden yang memiliki komunikasi efektif dengan orang tua berpeluang 6.827 kali berperilaku seksual positif dibandingkan dengan responden yang memiliki komunikasi tidak efektif dengan orang tuanya, akan tetapi hal ini tidak terbukti secara statistik (nilai $\mathrm{P}>0,05$ ).

\section{SARAN}

Berdasarkan hasil penelitian yang telah dilakukan ada beberapa saran yang perlu dijadikan pertimbangan bagi peneliti lainnya, antara lain :
1. Bagi orang tua

a. Menciptakan suasana keluarga yang akrab sehingga tercipta komunikasi yang terbuka antara orang tua dengan remaja termaksud komunikasi mengenai kesehatan reproduksi dan seksualitas.

b. Melakukan pendekatan khusus untuk mendampingi remaja dalam memilih teman dan lingkungan pergaulan serta penggunaan media pornografi yang saat ini semakin marak berkembang.

2. Bagi pelayanan keperawatan

a. Mengadakan penyuluhan, seminar, diskusi tentang kesehatan reproduksi untuk orang tua dan siswa, pengajar dan siswa dengan melakukan kerjasama dengan lembaga pemerintah, lembaga swasta atau LSM yang mempunyai kompetensi di bidang kesehatan reproduksi.

3. Bagi pendidikan

a. Sebagai bahan masukan atau referensi tambahan dalam penyampaian materi dalam proses belajar mengajar yang 
berkaitan dengan kesehatan reproduksi.

4. Bagi riset

a. Area penelitian perlu diperluas dengan jumlah sampel yang lebih representatif sehingga hasil yang diperoleh lebih memungkinkan

b. untuk dilakukan generalisasi pada populasi yang lebih besar.

c. Apabila menyusun penelitian yang sama agar menggunakan metode desain cross sectional, seperti case control, cohort atau experimental.

d. Hasil penelitian ini dapat digunakan sebagai data penelitian selanjutnya yang berkaitan dengan faktor-faktor lain yang mempengaruhi komunikasi orang tua dengan perilaku seksual remaja seperti sumber informasi dan teman sebaya.

\section{REFERENSI}

Amrilah 2007, 'Hubungan Antara Pengetahuan dan Kualitas Komunikasi Orang Tua dan Anak dengan Perilaku Seksual Pranikah' Artikel Indegeneous, di akses 15 maret 2014. http://eprints.ums.ac.id.

BKKBN 2008, Panduan Pengelolaan Pusat Informasi dan Konseling kesehatan Reproduksi Remaja, BKKBN Pusat, Jakarta.

BKKBN 2009, Pusat Informasi dan Konseling Remaja (PIK Remaja), Direktorat Remaja dan Perlindungan Hak-hak Reproduksi, Jakarta.

BKKBN 2010, Survey Kesehatan Reproduksi Tentang Persen Perilaku Remaja Berpacaran Dengan Gaya Berpacaran, Jakarta

Depkes RI 2006, Profil Kesehatan Indonesia, Depkes RI, Jakarta.

Depkes RI 2005, Strategi Nasional Kesehatan Remaja, Depkes RI, Jakarta.

Departemen Kesehatan RI 2002, Modul Kesehatan Reproduksi Remaja, Departemen Kesehatan RI, Jakarta.

Nurhayati, S 2011 'Hubungan Pola Komunikasi dan Kekuatan Keluarga dengan Perilaku Seksual Beresiko Pada Remaja di Desa Triyada Sakti kecamatan Tambun Selatan Kabupaten Bekasi', Fakultas Kesehatan Masyarakat Universitas Indonesia, Depok.

Muhammad 2006, Psikologi Remaja, Pustaka Setia, Bandung.

Sarwono \& Sarlito, W 2013, Psikologi Remaja, PT Raja Grafindo Persada, Jakarta.

Thera, YMU 2005, Kiat Mengatasi Kenakalan Remaja, di akses 1 April www.buddhistonline.com 